\title{
Gæði neysluvatns í ferðapjónustu á Íslandi
}

\author{
María J. Gunnarsdóttir og Sigurður Magnús Garðarsson
}

Fyrirspurnir:

\author{
Umhverfis- og byggingarverkfræðideild, Vatnaverkfræðistofa, Háskóla Íslands, Hjarðarhagi 6, 107 Reykjavík
}

María J. Gunnarsdóttir

mariag@hi.is

Greinin barst 10. október 2014.

Sampykkt til birtingar 15. desember 2014.

\section{ÁGRIP}

ABSTRACT

Ferðapjónusta er ört vaxandi atvinnugrein á Íslandi. Hún eykur álag á marga innviði samfélagsins par með talið stóraukið álag á vatnsveitukerfi í dreifbýli. Í pessari rannsókn var örveruástand hjá 444 minni vatnsveitum greint úr gagnagrunni um reglubundið eftirlit frá 7 heilbrigðiseftirlitssvæðum á Íslandi. Rannsakað̀ var hvernig neysluvatn uppfyllir reglugerð varðandi heildargerlafjölda, kólígerla, og E.coli. Niðurstöðurnar sýna að minnstu vatnsveitur í dreifbýli sem pjóna ferðamönnum hafa mun meira af örverum en aðrar í sama stærðarflokki og enn meiri munur er pegar borið er saman við vatnsveitur sem pjóna fleirum en 500 manns. Ástæður pessa eru líklega meðal annars erfiðleikar við að ráða við breytilegt árstíðabundið álag, takmörkuð pjónusta á afskekktum stöðum, og óljós ábyrgð.

Lykilorð: Ferðapjónusta, vatnsveitur, neysluvatnsgæði.
Tourism is a rapidly growing industry in Iceland, which increases pressure on the society infrastructure, including greatly increased stress on water supplies in rural areas. In this research microbiological condition at 444 small water utilities was analyzed based on data from regular surveillance from 7 Local Competent Authorities in Iceland. Compliance with the Icelandic drinking regulation with regard to Heterotrophic Plate Counts, Total coliform and E.coli was studied. The results show that the water supplies in rural areas that serve tourists have far more microbes than others in the same size class and there are even greater differences when compared to water supplies that serve more than 500 people. The reasons for this are likely to include an inability to cope with variable seasonal loads, limited service in remote locations, and unclear accountability.

Keywords: Tourism, water supply, drinking water quality.

\section{Inngangur}

Ferðapjónusta er ört vaxandi atvinnugrein á Íslandi. Síðan um aldamótin 2000 hefur árlegur fjöldi erlendra ferðamanna nær prefaldast og á sí̉asta ári, 2013, jókst tala peirra um 20\% á milli ára. Pessi hraða aukning hefur ýmis vandamál í för með sér fyrir innviði samfélagsins. Mörg ferðapjónustufyrirtæki eru í dreifbýli og er pjónað af litlum vatns- og fráveitum og álag er mjög breytilegt, oftast mest yfir sumartímann. Flestir ferðamenn heimsækja landið til að njóta náttúrunnar (Óladóttir, 2014) og er mikilvægt að á ferðamannastöðum sé fyrir hendi nóg vatn til drykkjar og hreinlætis.

Neysluvatn á Íslandi er oftast hreint, p.e. laust við sjúkdómsvaldandi örverur og efni sem eru hættuleg heilsu manna. Neysluvatn er skilgreint sem vatn ætlað til neyslu eða matargerðar og einnig vatn sem notað er í matvælafyrirtækjum. Í nýrri samantekt á neysluvatnsgæðum á Íslandi, unnin fyrir Matvælastofnun, kemur fram að örveruástand neysluvatns á Íslandi er í flestum tilfellum gott hjá stærri vatnsveitum, eða vatnsveitum sem pjóna fleirum en 500 íbúum en mun lakara hjá minni vatnsveitum eða peim sem pjóna færri en 500 (Gunnarsdóttir og Garðarsson, 2015). Einnig kemur fram að efnafræðilegt ástand neysluvatns er gott og sjaldgæft að pungmálmar eða eiturefni greinist í neysluvatni en flestar slíkar mælingar eru gerðar hjá stærri vatnsveitum en mun færri hjá peim minni pannig að lítið er vitað um efnafræðilegt ástand neysluvatns í dreifbýli (Gunnarsdottir o.fl., 2014).

Til að tryggja heilnæmi vatns er í gildi neysluvatnsreglugerð (nr. 536/2001) sem byggir á kröfum í tilskipun Evrópusambandsins um neysluvatn (EC, 1998). Markmið reglugerðarinnar er að vernda heilsu manna með pví að tryggja að neysluvatn sé heilnæmt og hreint. Par segir að vatnsveitur og aðrir sem dreifa neysluvatni skulu sjá til pessa að pað uppfylli kröfur um gæði og skal pað „vera laust við örverur, sníkjudýr og efni í pví magni sem getur haft áhrif á heilsu manna". Vatnsveitur bera pannig ábyrgð á að neysluvatn sé ekki skaðlegt heilsu manna og miðast sú ábyrgð við afhendingarstað í inntaksgrind í fasteignum. Húseigendur bera ábyrgð á heilnæmi neysluvatns innanhúss. Heilbrigðiseftirlit á hverju svæði hefur opinbert eftirlit með að ákvæðum neysluvatnsreglugerðarinnar sé framfylgt og Matvælastofnun hefur yfirumsjón fyrir hönd Atvinnuvega- og nýsköpunarráouneytisins (Gunnarsdóttir o.fl., 2015).
Starfsleyfis- og eftirlitsskyldar vatnsveitur skv. neysluvatnsreglugerð eru vatnsveitur sem pjóna 50 manns eða fleirum, eða 20 heimilum/ sumarbústöðum eða matvælafyrirtækjum. Petta pýðir að ef rekið er matvælafyrirtæki á staðnum pó íbúar séu færri en 50 pá er par eftirlitsskyld vatnsveita. Matvælafyrirtæki er skilgreint sem fyrirtæki eða aðili sem annast framleiðslu og dreifingu matvæla. Umfang eftirlitsins ræðst af fjölda íbúa með fasta búsetu. Stærri vatnsveitur á Íslandi eru flestar í eigu sveitarfélaga en minni vatnsveitur eru flestar í einkaeigu, p.e. í eigu notendanna sjálfra. Sérstaklega á petta við í minnsta flokknum, færri en 50 íbúar/matvælafyrirtæki. Heildarfjöldi vatnsveitna skv. ádurnefndri samantekt Matvælastofnunar er 797. Vatnsveitur á landinu með fleiri en 500 íbúum eru 49 talsins og pær pjóna um 94\% pjóðarinnar á meðan $6 \%$ fá vatn frá minni vatnsveitum eða einstökum vatnsbólum.

Markmið pessarar rannsóknar er að skoða hvernig vatnsveitur sem pjónusta ferðamenn í dreifbýli uppfylla kröfur neysluvatnsreglugerðarinnar um gæði neysluvatns samanborið við aðrar vatnsveitur. Jafnframt verður fjallað stuttlega um helstu pætti sem einkenna vatnsafhendingu í ferðapjónustu og hvað aðskilur hana frá öðrum vatnsveitum í dreifbýli og hvað er til ráđa ef úrbóta er pörf.

\begin{abstract}
Aðferðafræði
Til að skoða hvernig vatnsveitur í dreifbýli sem pjóna ferðamönnum uppfylla neysluvatnsreglugerðina voru fengnar niðurstöður sýnatöku í reglubundnu eftirliti frá árunum 2010 til og með 2012. Heilbrigðiseftirlitin taka sýni reglulega og senda til rannsóknarstofu til greiningar. Gögnin voru fengin frá Matvælastofnun. Valdar voru vatnsveitur með færri en 150 íbúum og eru skilgreindar sem eftirlitsskyldar. Sýni voru frá sjö af tíu heilbrigðiseftirlitssvæðum landsins og voru frá 416 vatnsveitum af peim 710 vatnsveitum sem eru af peirri stærð í landinu og skráđar eftirlitsskyldar. Síðan var bætt við sýnum frá 28 vatnsveitum sem pjóna fjallaskálum og annarri starfsemi í óbyggðum en ekki eru taldar eftirlitsskyldar. Margar peirra pjóna mörgum ferðamönnum. Alls voru pví 444 vatnsveitur í dreifbýli með í pessari rannsókn. Heilbrigðiseftirlitin hafa mismunandi reglur um hvaða vatnsveitur eru skráđar í minni flokkana pannig að hugsanlegt er að fjöldi
\end{abstract}


vatnsveitna, sérstaklega með færri en 50 íbúa séu fleiri en nú eru skrád.

Vatnsveiturnar 444 voru flokkaðar í prjár stærðarflokka (50-150 íbúar, <50 íbúar/matvælafyrirtæki, og fjallaskálar) og svo flokkaðar með og án ferðapjónustu. Fjöldi vatnsveitna án ferðapjónustu eru 237 og með ferðapjónustu 207. Tafla 1 sýnir fjölda vatnsveitna og sýna í hverjum flokki.

Skoðað var hvernig neysluvatn uppfyllir reglugerð í premur páttum, p.e. heildargerlafjölda við $22^{\circ} \mathrm{C}$, kólígerla og E.coli, sem allt eru eftirlitspættir sem eru vísar á lífræna mengun vatns. Skv. reglugerð er gert

Tafla 1 Fjöldi vatnsveitna og sýna í hverjum flokki. munur á fjölda sýna sem ekki uppfylltu neysluvatnsreglugerð með og án ferðapjónustu. Pegar skoðaðar voru vatnsveitur í dreifbýli með minna en 50 íbúa pá kom í ljós afgerandi munur í fjölda sýna sem ekki uppfylltu neysluvatnsreglugerðina. Til dæmis var fjöldi sýna með saurmengun (E.coli) 8,0\% í vatnsveitum án ferðapjónustu en 13,4\% með ferðapjónustu. Svipuð hlutfallsleg aukning var fyrir kólígerla og heildargerlafjölda (HGF). Staðan versnar svo enn pegar um fjallaskála er að ræða, sérstaklega er varðar heildargerlafjölda og 16,2\% sýna tekin í fjallaskála greindust með E.coli. Flest sýni á ferðamannastöðum voru tekin yfir sumarmánuðina, júní, júlí og ágúst, en hjá vatnsveitum

\section{Tegund vatnsveitur}

50-150 íbúar án ferðapjónustu

50-150 íbúar með ferðapjónustu

$<50$ íbúar án ferðapjónustu

$<50$ íbúar með ferðapjónustu

Fjallaskálar

Alls

ráð fyrir að mæla E.coli ef kólígerlar greinast og pví er fjöldi E.coli mælinga sá sami og kólígerla. Einnig var gerður samanburður við vatnsveitur með fleiri en 500 íbúa sem gert var grein fyrir í ádurnefndri skýrslu Matvælastofnunar.

Heildargerlafjöldi er ekki talinn gefa til kynna hvort um sjúkdómsvaldandi örverur sé að ræða par sem ekki hefur verið sýnt fram á fylgni við lýðheilsu en er frekar vísbending um hreinlæti (Bartram o.fl. 2003; WHO, 2011). Kólígerlar er flokkur baktería sem finnast í miklu magni í pörmum lífvera og víđa í umhverfinu. Tilvist peirra í vatni getur bent til áhrifa frá yfirborðsvatni, mengunar frá ópéttum frárennslisrörum eða leka frá rotpróm. Ef kólígerlar mælast skal samkvæmt reglugerð mæla E. coli. E.coli er baktería sem tilheyrir kólígerlaflokknum en er afbrigði sem lifir aðeins í pörmum lífvera með heitt blóð og kemur pví með saur manna og dýra, svo tilvist E.coli bendir pví til nýlegrar saurmengunar. Kröfur reglugerðarinnar eru að heildargerlafjöldi má mest vera 100 í einum ml en enginn kólígerill eða E.coli mega vera í 100 $\mathrm{ml}$.

\section{Niðurstöður}

Mynd 1 sýnir niðurstöður fyrir 444 minni vatnsveitur á Íslandi. Myndin sýnir að fyrir vatnsveitur sem pjóna 50-150 íbúum var óverulegur

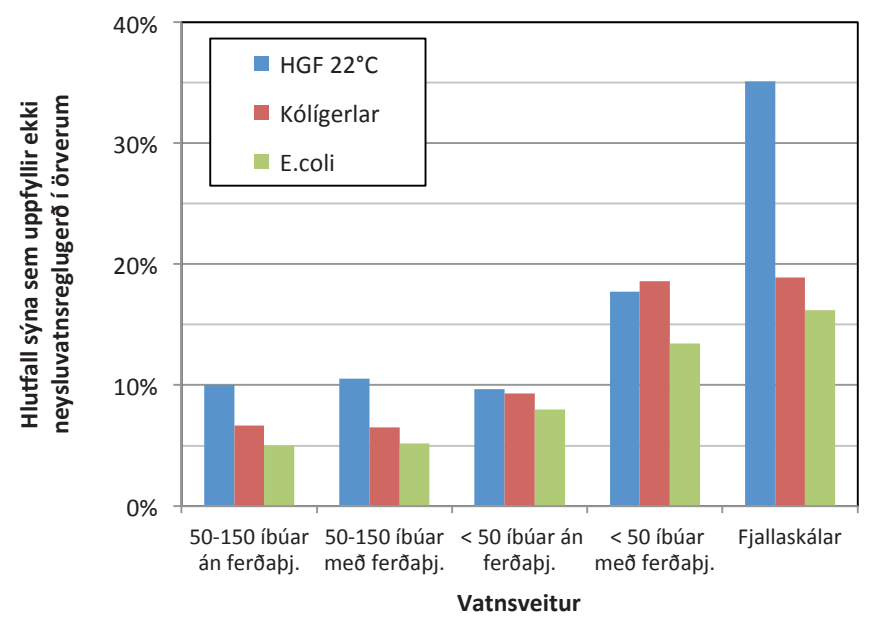

Mynd 1 Hlutfall sýna frá 444 vatnsveitum sem ekki uppfylla neysluvatnsreg/ugerð í örverum eftir stærð vatnsveitu og pjónustu við ferðamenn.
Fjöldi

vatnsveitna

21

39

216

140

28

444

705

Fjöldi sýna $2010-2012$

60

77

án ferðapjónustu af sömu stærð voru sýni tekin jafnar yfir árið, en pó fæst fyrstu prjá mánuði ársins og oft flest í desember. Hlutfall frávika eftir mánuðum er svipað allt árið í báðum flokkum sem gefur til kynna að tímasetning mælinga hafi ekki mikil áhrif á vatnsgæði.

Mynd 2 sýnir samanburð við stærri veitur. Par eru teknar saman allir flokkarnir á mynd 1 með og án ferðapjónustu og bornir saman við vatnsveitur með fleiri en 500 íbúa. Myndin sýnir að stóru veiturnar uppfylltu neysluvatnsreglugerðina mun betur en minni veitur. Einungis 0,9\% sýna hjá stæri veitum greindust með E.coli á meðan sýni hjá minni veitum með og án ferðapjónustu greindust í 7,5\% og 11,9\%

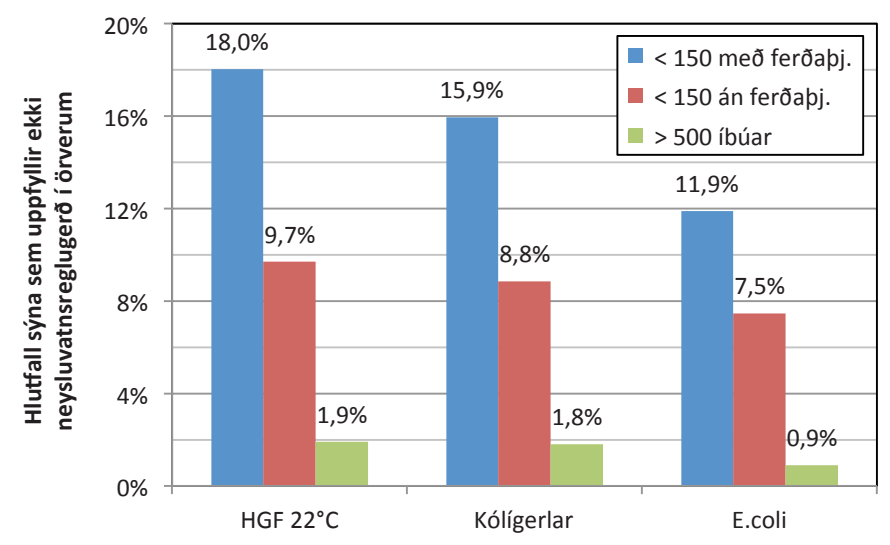

Mynd 2 Hlutfall sýna sem uppfylla ekki neysluvatnsreglugerð eftir tegund og stærð vatnsveitu.

tilfella með E.coli.

Sýnatökufjöldinn var skv. töflu 1 um 0,5 sýni á ári á hverja vatnsveitu sem pýðir að sýni eru að meðaltali tekin annað hvert ár hjá öllum 444 vatnsveitunum. Pað er í samræmi við lágmarkskröfur neysluvatnsreglugerðarinnar fyrir vatnsveitur sem pjóna færri en 150 íbúum.

\section{Umræður}

Niðurstöðurnar sýna að vatnsgæði hjá minni vatnsveitum er mun lakari en hjá stærri veitum. Niðurstöðurnar sýna einnig að pessar minni veitur sem pjóna aðallega ferðamönnum koma verr út en pær 
sem pjóna ekki eða að litlu leyti ferðamönnum. Petta á sérstaklega við veitur sem pjóna færri en 50 íbúum, en fyrir veitur sem pjóna 50-150 pá er munurinn ekki afgerandi. Fjallaskálar koma sérstaklega illa út úr samanburðinum, sérstaklega hvað varðar heildargerlafjölda, en pó er hlutfallsleg aukning E.coli ekki jafnmikil.

Pessar niðurstöður ríma vel við athuganir á hvar vatnsbornir faraldar hafa orðið hér á landi en flestir peirra hafa orðið hjá vatnsveitum sem pjóna ferðamönnum og sumarhúsagestum og allir hjá minni vatnsveitum (Briem, 2005; Atladóttir, 2006; Geirsdóttir, 2011; Gunnarsdottir o.fl., 2012; Gunnarsdottir o.fl. 2013). Almennt er talið að oftast séu pað fleiri en einn páttur sem fer úrskeiðis pegar slíkir faraldrar verða og hafa sumir pættir stundum verið í ólagi lengi (Hrudey o.fl. 2006). Einnig er pekkt að örveruástand sé lakara hjá minni veitum en peim stærri vída í heiminum og talið að orsökin sé skortur á fjármögnun, starfsfólki og fræðslu (WHO, 1997; Hulsmann, 2005; WHO-EU, 2011). Beaudeau o.fl. (2010) komust að peirri niðurstöðu að E.coli yfir 20 í 100 ml er átta sinnum líklegra í vatnsveitum í Frakklandi sem pjóna færri en 100 íbúum en veitum sem pjóna 500 til 2000. Vatnsveitur með færri en 100 íbúa í Frakklandi eru flestar til fjalla og á vinsælum ferðamannastöðum. Pitkänen o.fl. (2011) komust аð peirri niðurstöðu að saurmengun væri mun algengari hjá vatnsveitum í Finnlandi sem pjónuðu færri en 250 manns en peim stærri.

Skýringin á pví hversvegna örverur eru ennpá tídari hjá vatnsveitum sem pjóna ferðamannastöðum en hjá öðrum í sama stærðarflokki gæti verið að pær fyrrnefndu eru á ýmsan hátt frábrugðnar öðrum vatnsveitum; álag er mismunandi eftir árstíma, vinsælir ferðamannastaðir eru flestir í dreifbýli og stundum á mjög afskekktum stöðum par sem afar takmörkuð pjónusta er til staðar, oft er óljóst hver ber ábyrgð á að fyrirbyggja mengun og grípa til nauðsynlegra aðgerða. Sumir ferðamannastaðanna fá til sín mikinn fjölda gesta á dag yfir sumartímann en mun færri yfir vetrartímann. Til dæmis hefur verið áætlað að yfir sumarið heimsæki 30-40 púsund manns Hveravelli á Kili og um 100 púsund manns Landmannalaugar (Pórólfsdóttir, 2012; Aradóttir, 2003). Um 70\% erlendra ferðamanna fara Gullna hringinn eða um 650 púsund manns á ári og par gætu verið um nokkur púsund manns á annasömum degi (Óladóttir, 2014).

Fjöldi ferðamanna sem heimsækja Ísland hefur aukist mjög hratt á undanförnum árum eins og sjá má í árlegri samantekt Ferðamálastofu „Ferðapjónusta Íslands í tölum" (Óladóttir, 2014). Áætlaður fjöldi erlendra ferðamanna sem heimsóttu Íslands árið 2013 var um 900 púsund manns og af peim komu 92 púsund með skemmtiferðaskipum. Um 88\% Íslendinga ferðast um landið á ári hverju eða um 280 púsund manns og margir dvelja í sumarhúsum, ýmist sínum eigin eða á vegum stéttarfélaga.

Til að áætla aukið álag á vatnsveitur í dreifbýli frá ferðapjónustu var miðað við samantekt Gössling o.fl. (2012) á vatnsnotkun í ferðapjónustu í 54 löndum og gögnum frá Ferðamálastofu (Óladóttir, 2014). Meðaldvalarlengd erlendra ferðamanna í pessum 54 löndum er 8,5 dagar samanborið við 10,4 dagar á Íslandi. Meðalvatnsnotkun er samkvæmt samantekt Gössling o.fl. (2012) 286 lítrar á hvern ferðamann á dag. Par sem hátt hlutfall af ferðamennsku er til fjalla og á litlum gististöðum er notkunin 150 lítrar á ferðamann á dag en um 400 lítrar á dag á ferðamannastöðum við Miðjarðarhafið. Út frá pessum forsendum (150 I/dag; 900 púsund ferðamenn; 10,4 daga) pá má áætla heildarvatnsnotkun erlendra ferðamanna á Íslandi yfir árið um 1,4 Mm3/ári samanborið við ríflega 23 Mm3/ári (200 l/dag; 320 púsund íbúar; 365 daga) fyrir búsetta Íslendinga. Petta pýðir pví að meðaltali er notkun ferðamanna um $6 \%$ af neysluvatni til heimilisnota sem er með pví hæsta sem gerist í heiminum samkvæmt Gössling o.fl. (2012), en par kemur fram að meðaltal landanna 54 er 0,58\% og aðeins 5 lönd hafa hærra hlutfall en 6\% (Máritíus, 20,2\%; Kýpur, 17,4\%; Malta, 11,9\%; Barbados, 9,4\%; Spánn, 6,3\%).
Aukning í árstíðarbundnu álagi í dreifbýli má meta með pví að miða við gistinætur í júlí pegar ferðamannafjöldi er mestur og nota tölur um gistinætur frá Ferðamálastofu (Óladóttir, 2014). í júlí 2013 eru gistinæturnar útlendinga 458 púsund og Íslendinga 62 pús. Út frá gögnum Ferðamálastofu má gróflega áætla að 15-30\% pessara nótta er eytt í húsnæði sem fær neysluvatn frá minni vatnsveitum. Til samanburðar pá eru um 20 púsund Íslendingar (6\% af 320 púsund) sem er pjónað af pessum sömu vatnsveitum, eða um 600 púsund dvalarnætur á mánuði. Miðað við pessar forsendur eykst álagið á litlar vatnsveitur að meðaltali um 13-26\% í júlí sem er umtalsvert og líklegt að aukningin sé mun meiri á sumum stöðum.

Hönnun vatnsveitna með árstíðarbundnu álagi eins og tengist pjónustu við ferðamenn er hægt að leysa með ýmsum hætti og fer pað eftir aðstæðum á hverjum stað hvaða lausn hentar. Tæknilegar lausnir geta verið margskonar. Par má nefna borholu sem hægt er tengja pegar ferðamannatímabilið hefst, aukadælu sem sett er af stað pegar álag eykst, hraðastýringu á dælur og aukið miðlunarrými. Par sem stór eða allur hluti kerfisins er ónotaður utan ferðamannatímans er nauðsynlegt að hafa skýrar verklagsreglur pegar kerfið er tekið úr notkun og pegar pað sett af stað aftur. Par má nefna að yfirfara og skola kerfið vandlega áður en pað er tekið í notkun. Nauðsynlegt er að taka sýni og mæla örverur a.m.k. við upphaf tímabilsins en varla nægjanlegt að gera pað annað hvert ár eins og nú er gert.

Stofnkostnaður, rekstur, og viðhald vatnsveitna á ferðamannastöðum getur verið umtalsverður og pví parf að finna leiðir til að kerfin verði sjálfbær er varðar kostnað. Á mörgum stöðum liggur nú pegar fyrir að bæta purfi innviði, bæði hvað varðar neysluvatn, almenningssalerni og fráveitur almennt. Opinberir eftirlitsaðilar purfa að skilgreina hvað er eftirlitsskyld ferðapjónusta, setja upp reglubundið eftirlit, hvetja til innra eftirlits, og útbúa leiðbeiningar fyrir ferðapjónustuaðila um vatns- og fráveitumál, t.d. í formi gátlista.

\section{Samantekt}

Ferðapjónusta er orðinn umfangsmikill á Íslandi og nota ferðamenn hátt hlutfall af íslensku neysluvatni til heimilisnota samanborið við flest önnur lönd. Fyrirliggjandi gögn reglubundins eftirlits gefa til kynna að gæði neysluvatns vatnsveitna á ferðamannastöðum á Íslandi séu talsvert lakari en á samsvarandi stöðum sem ekki pjónusta ferðamenn í miklum mæli. Nauðsynlegt er fyrir opinbera aðila og pá sem bera ábyrgð á ferðamannastöðum að bregðast við með pví að styrkja innviði, setja upp reglubundið eftirlit, og útbúa leiðbeiningar um hvernig best sé staðið að pví að afhenda neysluvatn sem uppfyllir parfir ferðamanna.

\section{Heimildir}

Aradóttir, B. (2003): Polmörk innviða í Landmannalaugum. Í: Polmörk ferðamennsku í Landmannalaugum. Bergpóra Aradóttir (ritstjóri), Akureyri, Ferðamálaráo Íslands, Háskóli Íslands, Háskólinn á Akureyri og Ferðamálasetur Íslands, 9-24.

Atladóttir, A. (2006). Outbreaks of Norovirus Infections in Two tourist Resorts in Iceland in the Summer of 2004. 5. Nordic Water Supply Conference 8-10 June 2006 in Reykjavik. Proceeding bls. 67-70.

Bartram, J., Cotruvo, J., Exner, M., Fricker, C., Glasmacher, A. (2003). Heterotrophic Plate counts and Drinking-water Safety. The significance of HPCs for Water Quality and Human Health. IWA London.

Beaudeau, P., Valdes, D., Mouly, D., Stempfelet, M. \& Seux, R. (2010). Natural and technical factors in faecal contamination incidents of drinking water in small distribution networks, France, 2003-2004: a geographical study. J. Water Health 8(1):20-34.

Briem, H. (2005). Nóróveirusýkingar yfir sumarmánuðina. Farsóttafréttir Júní 2005.

European Council (1998). Directive 98/83/EC of 3 November 1998 on the quality of water intended for human consumption.

Geirsdóttir, M. (2011). Óopinber listi yfir vatnsborna faraldra. Matís ohf.

Gunnarsdottir, M.J., Gardarsson, S.M., Elliott, M., Sigmundsdottir, G., Bartram, J. (2012). Benefits of Water Safety Plans: Microbiology, Compliance, and 
Public Health. Environmental Science \& Technology , 46, 7782-7789.

Gunnarsdottir, M.J., Gardarsson, S.M., Andradottir, H.O. (2013). Microbial contamination in groundwater supply in cold climate and coarse soil: Case study of norovirus outbreak at Lake Mývatn, Iceland. Hydrology Research Vol 44 No 6 pp 1114-1128. doi:10.2166/nh.2013.076

Gunnarsdottir, M.J., Gardarsson, S.M., Jonsson, G.S., Armannsson, H. \& Bartram J. (2014). Natural background levels for chemicals in Icelandic aquifers. Í prentun.

Gunnarsdottir, M. J., Gardarsson, S. M., and Bartram, J. (2015). Developing a national framework for safe drinking water - Case study from Iceland. Int. J. Hyg. Environ. Health. 218; 196-202; DOI 10.1016/j.ijheh.2014.10.003 Gunnarsdottir, M.J. and Gardarsson, S.M. (2015) Gæði neysluvatns á Íslandi 2002-2012. Skýrsla unnin fyrir Matvælastofnun. Mars 2015 http://www. mast.is/library/Skýrslur/Gaedineysluvatnsalslandi150331.pdf

Gössling, S., Peeters, P., Hall, C.M., Ceron, J.P., Dubois, G. (2012). Tourism and water use: Supply, demand, and security. An International review. Tourism Management 33, 1-15.

Hrudey, S.E., Hrudey, E.J., \& Pollard, S.J.T. (2006). Risk management for assuring safe drinking water. Environ. Int., 32(8), 948-957.
Hulsmann A. (2005). Small systems large problems: A European inventory of small water systems and associated problems. Nieuwegein, Web-based European Knowledge Network on Water (WEKNOW).

Óladóttir, O.P. (2014). Ferðapjónusta á Íslandi í tölum, Apríl 2014. Samantekt Ferðamálastofa.

Pitkänen, T., Karinen P., Miettinen, I.T., Lettojärvi, H. Hekkilä A., Maunula, R., Aula, V., Kuronen, H., Vepsäläinen, A., Nousiainen, L. Pelkonen, S., Heinonen-Tanski, H. (2011). Microbial Contamination of Groundwater at Small Community Water Supplies in Finland. AMBIO 40, 377-390.

Umhverfisráðuneytið (2001). Reglugerð nr. 536/2001 um neysluvatn.

WHO (1997). Guidelines for drinking water quality. Volume 3: Surveillance and control of community supplies, 2nd edn. Geneva Switzerland: World Health Organization.

WHO (2011). Guidelines for Drinking- water quality, fourth edition. Geneva, World Health Organization.

WHO-EU (2011). Small-scale water supplies in the pan-European region. Background- Challenges-Improvements. World Health Organization. Regional office for Europe.

Pórólfsdóttir, B.Ó.P. (2012). Heilnæmi og öryggi laugarvatns á náttúrulegum baðstöðum. Meistararitgerð við Háskóla Íslands.
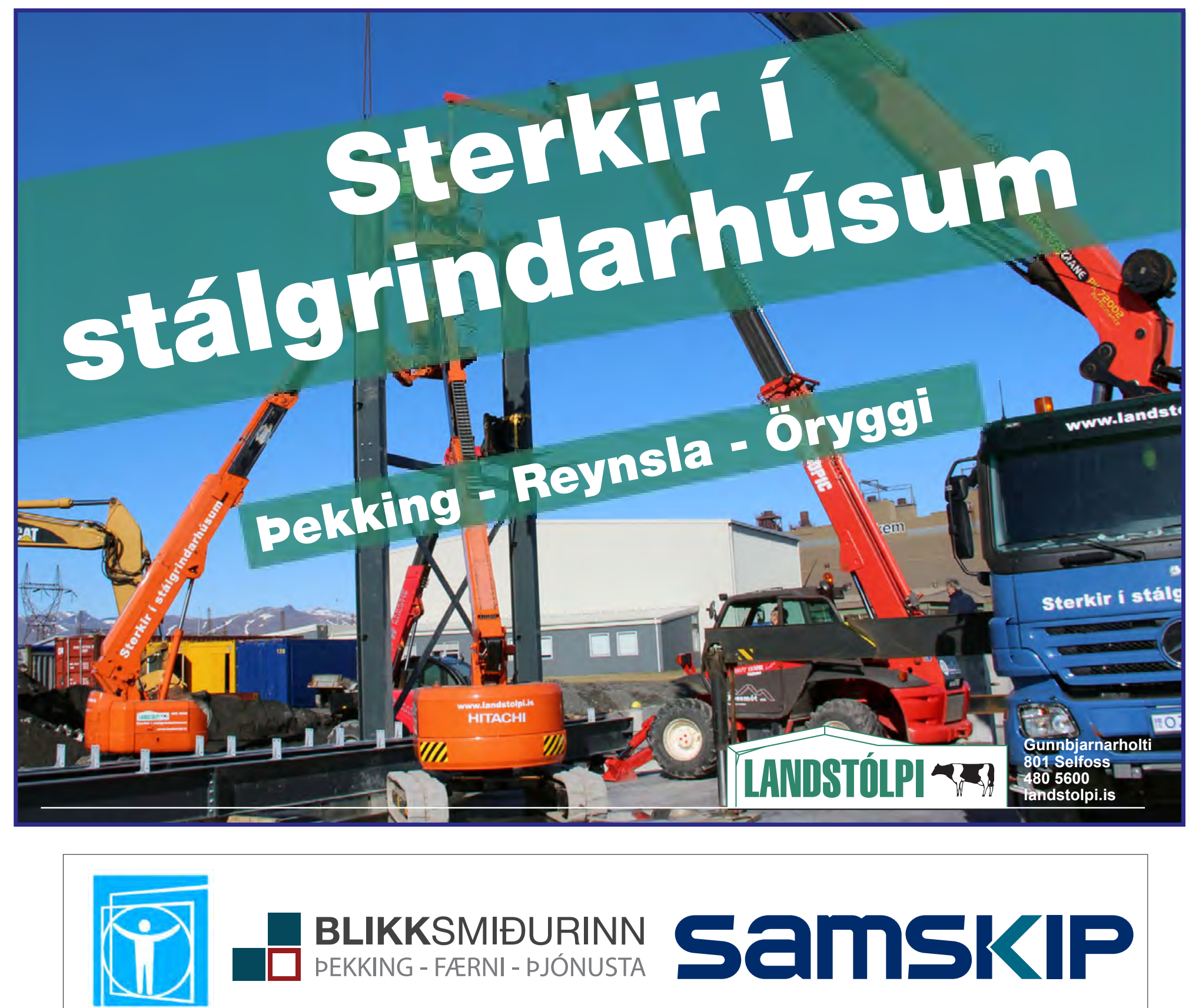

BLIKKSMIĐURINN

PEKKING - FARNI - PJÓNUSTA

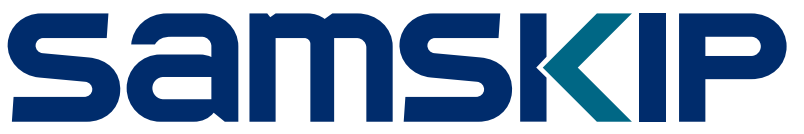

TLELAEAD IS ANDS STADDLAR 